\title{
Eating Quality of Beef from Arsi, Borana, and Harar Cattle Breed, Oromia National Regional State, Ethiopia
}

\author{
Timketa Dagne Tefera1, Yesihak Yusuf Mummed², Mohammed Yusuf Kurtu², \\ Mengistu Urge Leta ${ }^{2}$, Travis Gene O'Quinn'3 ${ }^{3}$ Jessie L. Vipham ${ }^{3}$ \\ ${ }^{1}$ Department of Animal Science, College of Agriculture, Oda Bultum University, Chiro, Ethiopia \\ ${ }^{2}$ School of Animal and Range Sciences, College of Agriculture and Environmental Sciences, Haramaya University, Dire Dawa, \\ Ethiopia \\ ${ }^{3}$ Department of Animal Sciences and Industry, Kansas State University, Manhattan, USA \\ Email: yesihakyus@gmail.com
}

How to cite this paper: Tefera, T.D., Mummed, Y.Y., Kurtu, M.Y., Leta, M.U., O'Quinn, T.G. and Vipham, J.L. (2021) Eating Quality of Beef from Arsi, Borana, and Harar Cattle Breed, Oromia National Regional State, Ethiopia. Open Journal of Animal Sciences, 11, 255-268. https://doi.org/10.4236/ojas.2021.112020

Received: September 30, 2020

Accepted: April 25, 2021

Published: April 28, 2021

Copyright $\odot 2021$ by author(s) and Scientific Research Publishing Inc. This work is licensed under the Creative Commons Attribution International License (CC BY 4.0).

http://creativecommons.org/licenses/by/4.0/

\begin{abstract}
The objective of this study was to evaluate the eating qualities of Arsi, Borana, and Harar Cattle breeds in Ethiopia. A total of 39 bulls with age categories of $<3,4-6$, and $7-9$ years were used for the study. The bulls were purchased from mixed crop-livestock systems (Arsi and Harar) and Ranch (Borana) and slaughtered to evaluate the eating quality. WBSF device was used to evaluate instrumental tenderness while sensory panel testing was used to evaluate sensory tenderness, juiciness and flavor. The color of the meat was evaluated using Hunter Lab Mini Scan EZ while water holding capacity was evaluated using filter papers. A complete randomized design was used for the study. Breed significantly affected $(\mathrm{P}<0.0001)$ instrumental tenderness with beef from Harar and Boran bulls were very tender $(18.55 \pm 5.34,20.34 \pm 4.06 \mathrm{~N}$, respectively) while beef from Arsi bulls intermediate in tenderness (40.60 \pm $0.51 \mathrm{~N}$ ). Beef from all age group of Harar and Boran breeds were very tender while beef from the Arsi breed was very tender for age $<3$ years, intermediate for $4-6$ and tough for age group $>7$ years of age. Flavor and juiciness was significantly $(\mathrm{P}<0.05)$ affected by breed. Flavor from Harar and Boran breeds were moderately liked while flavor from Arsi was liked slightly. Beef from Boran breed was ranked juicier than beef from Harar and Arsi breed. Borana $\left(<3\right.$ years) beef was higher $(P<0.05)$ in lightness $\left(L^{*}\right)$ than Arsi and Harar indicating more quality beef from Borana breed. From the study it was concluded that Arsi bulls older than four years of age produced tougher beef suggesting the use of this breed for beef at early age while beef from Borana and Harar breed can be used to 9 years of age as they produce very tender meat.
\end{abstract}




\section{Keywords}

Beef, Tenderness, Juiciness, Flavor, Color

\section{Introduction}

In Ethiopia, the demand for livestock products is increasing due to the growing urban population, while farm areas are shrinking much as a result of an increase in the rural population [1]. However, for beef to remain competitive in the marketplace, the product must satisfy the demands of consumers. Poor eating quality is seen as a major factor in the decline in beef consumption [2]. Three main factors that make up beef quality are safety (wholesomeness), nutritional quality, and palatability. Palatability is determined by tenderness, juiciness, and flavor. Meat-eating quality involves five attributes namely, color, water holding capacity, tenderness, juiciness, and flavor [3].

Very little research has been conducted concerning meat production in Ethiopia and in particular, on carcass quality of beef cattle [4]. Meat yield and the percentage were reported about $61 \mathrm{~kg}$ and 67\%, respectively in the Northern part of Ethiopia (Mummed and Webb, 2019). Lower meat yield percentage in the range of $32 \%-58 \%$ was also reported in the country [5]. Continuous assessment of meat eating qualities was suggested to satisfy the demand of consumers. Consistency of auditing of meat quality at the interval of time is to sustain livestock production that would yield consistent quality to consumers [6]. One of the factors that affect the competitiveness of Ethiopian meat in the Middle East Market was the quality of beef [6]. Few studies were conducted to evaluate the quality of beef produced from local cattle breeds using instrumental methods and scanty research was available using sensory panel testing. Instrumental method using WBSF device is the best option to compare the quality across age and breeds as sensory panel testing is subjective between individuals involved in panel testing [7]. Based on these gaps, this research was designed with the objective to evaluate the eating quality of beef from Arsi, Borana, and Harar cattle breeds based on instrumental tenderness and sensory panel testing.

\section{Materials and Methods}

\subsection{Descriptions of the Study Areas}

The animals were purchased from West Arsi Zone (Kofelle), Borena Zone (Yabello), and West Hararge Zone (Chiro), Ethiopia. West Arsi Zone is located 250 $\mathrm{km}$ south of Addis Ababa/Finfinnee, the capital city of Ethiopia, and is found in the Rift Valley Region (Figure 1). The mean annual temperature of the zone is found between $20^{\circ} \mathrm{C}-25^{\circ} \mathrm{C}$. Kofale district is located $280 \mathrm{~km}$ south of Addis Ababa/Finfine, the capital city of Ethiopia and located at $7^{\circ} 19^{\prime} \mathrm{N}$ to $7^{\circ} 40^{\prime} \mathrm{N}$ and $38^{\circ} 30^{\prime} \mathrm{E}$ to $38^{\circ} 53^{\prime} \mathrm{E}$. It has erratic type of bimodal rainfall. West Hararge zone is found $326 \mathrm{~km}$ east of Addis Abab/Finfinnee, the capital city of Ethiopia. West 
Hararge zone is located at $8^{\circ} 40^{\prime} 0^{\prime \prime} \mathrm{N}, 40^{\circ} 30^{\prime} 0^{\prime \prime} \mathrm{E}$ and altitude between 970 and 1410 meters above sea level. The annual rainfall ranges (include from or between) 650 - $950 \mathrm{~mm}$ and means temperature range (include from or between) $17.5^{\circ} \mathrm{C}-27^{\circ} \mathrm{C}$. Mixed crop livestock production is practiced in Arsi and Hareghe regions. Grazing and crop residue are the major feed resource in these regions.

Borana Zone of Yabello district and is situated about $550 \mathrm{~km}$ south of Addis Ababa/Finfinnee, the capital city of Ethiopia and $20 \mathrm{~km}$ north of Yabello town. Borana zone is semi-arid with an average rainfall ranging (include from) 300 $600 \mathrm{~mm}$ and an average daily temperature of $19^{\circ} \mathrm{C}$ to $26^{\circ} \mathrm{C}$. The zone is located at $4^{\circ} 53^{\prime} \mathrm{N} 38^{\circ} 5^{\prime} \mathrm{E}$. Extensive grazing on natural pasture dominated by perennial grasses (Cenchrus, Pennisetum, and Chrysopogoies) species is practiced in this area. The area has a bimodal rainfall distribution with long rains extending from March to May and short rains from September to November.

\subsection{Sampling Procedure and Experimental Animals}

A total of 39 bulls from three breeds of cattle namely, Harar, Arsi and Borana were used for the study. Bulls were purchased from their niche market. Harar and Arsi bulls were purchased from Chiro and Kofale local markets, respectively. Borana bulls were purchased from Yabello (Didu Tiyura) Ranch. The bulls were categorized into three age groups that include $<3,4-6$ and $7-9$ years. The ages of the bulls were determined based on dentition. After purchased individual bulls were ear-tagged and transported by vehicles to Elfora abattoir at Bishoftu.

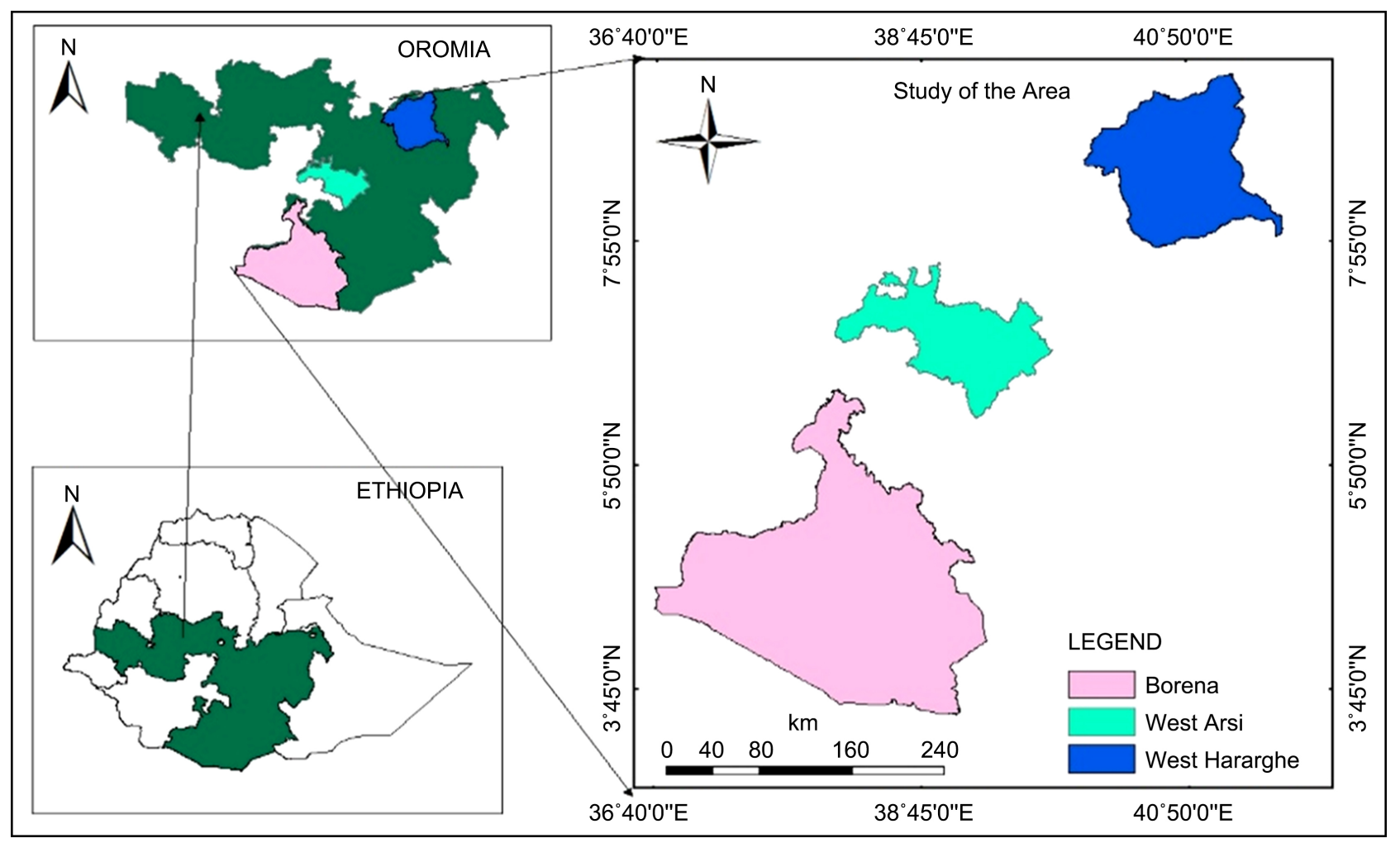

Figure 1. Map of the study area. 


\subsection{Slaughter Procedures and Sampling}

After lairrage rest pre-mortem examinations were taken immediately before slaughter. Bulls were slaughtered by the enervation method. After bleeding, flying off the hide, and removing the viscera. Postmortem examinations were made by veterinarians at the abattoir. After sawed into the right and left half, the carcass was chilled for 24 hours at $4^{\circ} \mathrm{C}$. After chilling, the left sides of each carcass were separated at the $12^{\text {th }}$ and $13^{\text {th }}$ ribs to take beef samples for eating quality determination from the Longissimus dorsi muscle.

\subsection{Evaluation of Eating Quality (Sensory and Instrumental Tenderness)}

\section{Meat Sample Collection and Transport to Laboratory}

About $0.5 \mathrm{~kg}$ meat samples were taken from Longissimus dorsi $(L D)$ muscle between $12^{\text {th }}$ and $13^{\text {th }}$ ribs within $24 \mathrm{hrs}$ after slaughters and were packed into a plastic bag, sealed into a vacuum, stored in the icebox and then transported to Oda Bultum University Animal Science laboratory. The samples were aged in deep freeze for 14 days before steaks were prepared for sensory and instrumental tenderness analysis.

\subsubsection{Eating Quality Evaluation Using Sensory Panel Testing}

Twelve semi-trained panelists among Oda Bultum University Dairy and Meat technology Department students were selected based on their interest, familiarity with beef and ability to express the meaning of scales rate used in evaluation of meat. The panelists were trained on the procedures and principles of sensory evaluation according to the procedures described by [8]

Each Batch of aged samples was thawed for 24 hours at room temperature $\left(24^{\circ} \mathrm{C}-25^{\circ} \mathrm{C}\right)$ for steaks preparation. The steaks were prepared according to procedures developed by [8]. Cooking pan was heated for about $205^{\circ} \mathrm{C}$ before placing the steak on the pan. The steak was cooked until the internal temperature reached $70^{\circ} \mathrm{C}$.

The steaks were uniformly cut to reduce any bias related to serving position and presented in white color plate randomly. Each assessor has evaluated three most important eating quality (tenderness, juiciness, and flavor) parameters. The evaluators scored each sample on a nine-point hedonic scale for tenderness, flavor and juiciness. They filled in three-digit of sensory codes, which indicated panelists codes, treatment codes, and sensory variables. Before actual testing, a warm-up sample was served first, and then preceded to experimental samples steak in the next testing sessions. Between each sample tasted, clean water was served for calibration of the panelist taste [8]. Nine hedonic scale rating was used to evaluate the meat by sensory panel testing. The 9-point scales used to assess meat quality attributes were: Flavour: $9=$ like extremely, $8=$ like very much, 7 = like moderately, $6=$ like slightly, $5=$ neither like nor dislike, $4=$ dislike slightly, 3 = dislike moderately, 2 = dislike very much, $1=$ dislike extremely, Tenderness: $9=$ extremely tender, $8=$ very much tender, $7=$ moderately tender, 
$6=$ slightly tender, $5=$ neither tender nor tough, $4=$ slightly tough, $3=\bmod -$ erately tough, 2 = very much tough, $1=$ extremely tough; and Juiciness: $9=$ extremely juicy, $8=$ very much juicy, $7=$ moderately juicy, $6=$ slightly juicy, $5=$ neither juicy nor dry, 4 = slightly dry, 3 = moderately dry, 2 = very much dry, 1 $=$ extremely dry.

\subsubsection{Instrumental Tenderness Determination}

\section{1) Warner-Bratzler Shear Force (WBSF) Method}

The Warner-Bratzler shear force method was used to determine instrumental tenderness. The steak which was cooked for $70^{\circ} \mathrm{C}$ was allowed to cool down to room temperature for about an hour to evaluate instrumental tenderness using WBSF. The same cooking procedure described sensory panel testing above was used to cook the steak for evaluation of instrumental tenderness. After cooling, the steak was cut across the long axis putting the knife tip on heavy connective tissue side (dorsal) and handle of the knife on ventral side in order to expose the fiber direction. Six cores were removed parallel with the muscle fibers. It was critical that the muscle fibers run parallel with the core so that the shear was across the grain. The WBSF device was used to shear each core. The shear was across the middle (center) on each core. The peak values of WBSF were recorded in $\mathrm{N}$ (Newton) for each core. The average values for the six cores were taken for the determination of the value for each steak. The samples of meat was classified in to very tender, tender, intermediate and tough based on the range of value of WBSF which classified WBSF value in to very tender $=$ WBS $<31.4 \mathrm{~N}$, tender $=$ $31.4 \mathrm{~N}<\mathrm{WBS}<38.3 \mathrm{~N}$, intermediate $=38.3 \mathrm{~N}<\mathrm{WBS}<45.1 \mathrm{~N}$ and tough $=$ WBS $>45.1$ [9].

\section{2) Determination of Water Holding Capacity}

Water-holding capacity of meat was measured using the method developed by [10] [11]. A $0.5 \mathrm{~g}$ of chilled meat was weighed and placed between two filter papers. This in turn was placed between two glass sheets. Over it, a weight of 4.015 $\mathrm{kg}$ load was placed while the glass sheet weighed $0.8278 \mathrm{~kg}$, giving a total compression weight of $4.8428 \mathrm{~kg}$ for $5 \mathrm{~min}$. The water from the meat was then absorbed on the filter paper and the filter paper was dried. Then the area of the filter paper marked with the juice from the meat was later determined using a compensatory planimeter. Taking differences from the resulting areas of the sample from a marked borderline on the filter paper (moisture) and meat and a ratio area marked borderline was expressed as water holding capacity of the meat (WHC):

$$
\mathrm{WHC}=\frac{(\text { Area marked borderline }- \text { area meat })}{\text { Area marked borderline }} \times 100
$$

\section{3) Color Determination}

Meat color was determined according to the established procedure [8]. Meat samples were cut in cross-section perpendicular to the long axis of muscle with $2.54 \mathrm{~cm}$ thickness against a white background. The cut meat samples were exposed to air for $30 \mathrm{~min}$ to bloom at $4^{\circ} \mathrm{C}$, then the $\mathrm{L}^{\star}, \mathrm{a}^{\star}, \mathrm{b}^{\star}$ measured at room 
temperature $\left(24^{\circ} \mathrm{C} \pm 1.2^{\circ} \mathrm{C}\right)$ using HunterLab MiniScan EZ (MSEZ-4500L, Serial No. MsEZ1547, 45/ $0^{\circ}$ illumination/viewing system, D65 light source, and $10^{\circ}$ observer angle). Three random readings at different locations per sample were taken and averaged. Then, the instrument was calibrated with black and white standardized tiles before taking color measurements of the next sample.

\subsection{Experimental Design}

A factorial arrangement with two factors (age and breed) in the CRD (Completely Randomized Design) was used for the study. The treatment composition was indicated in Table 1.

\subsection{Statistical Analysis}

The data were analyzed by the procedure of General Linear Model (GLM) using SAS software (SAS, 2009). When the GLM showed the presence of significant difference between the different parameters, the Duncan's multiple range tests were used for mean separation.

The model used for the analysis was:

$$
Y_{i j k}=\mu+\beta_{1 i}+\beta_{2 j}+(\beta 1 \beta 2) i j+e_{i j k}
$$

where;

$Y_{i j k}=$ the response variables,

$\mu=$ the overall Mean,

$\beta_{1 i}=$ the effect of Age,

$\beta_{2 j}=$ the effect of breed,

$(\beta 1 \beta 2) i j=$ The effect of interaction between age and breed, $e_{i j k}=$ Random error.

\section{Results and Discussion}

\subsection{Effect of Age and Breeds of Cattle on Beef Eating Quality}

\subsubsection{Effect of Age and Breeds of Cattle on Sensory Characteristics of Beef Cattle}

The effect of age and breeds of cattle on beef sensory characteristics of Arsi, Borana and Harar were summarized in Table 2. Age and breeds of cattle have a significant effect $(\mathrm{P}<0.05)$ on sensory characteristics (flavor, Juiciness and tenderness). However, quality characteristics of beef from the breeds and age

Table 1. Treatment composition.

\begin{tabular}{ccccc}
\hline \multirow{2}{*}{ Cattle Breeds } & \multicolumn{3}{c}{ Age (Years) } & Total \\
\cline { 2 - 4 } & $<3$ & 4 to 6 & 7 to 9 & \\
\hline Arsi & 5 & 3 & 3 & 11 \\
Borana & 5 & 5 & 4 & 14 \\
Harar & 5 & 5 & 4 & 14 \\
Total & 15 & 13 & 11 & 39 \\
\hline
\end{tabular}


Table 2. Effect of age and breeds of cattle on sensory characteristics and instrumental tenderness.

\begin{tabular}{|c|c|c|c|c|c|}
\hline \multirow{3}{*}{ Parameters } & \multirow{3}{*}{ Age } & \multicolumn{3}{|c|}{ Breeds } & \multirow{3}{*}{$\mathrm{P}$ value } \\
\hline & & Arsi & Borana & Harar & \\
\hline & & Mean \pm SD & Mean \pm SD & Mean \pm SD & \\
\hline \multirow{3}{*}{ Flavor } & $<3$ & $6.52^{b} \pm 0.25$ & $6.97^{\mathrm{ab}} \pm 0.25$ & $6.77^{\mathrm{a}} \pm 0.24$ & $* *$ \\
\hline & $4-6$ & $7.42 \pm 0.33$ & $7.10 \pm 0.45$ & $7.38 \pm 0.15$ & NS \\
\hline & $7-9$ & $7.28^{\mathrm{b}} \pm 0.39$ & $8.21^{\mathrm{a}} \pm 0.17$ & $7.71^{\mathrm{ab}} \pm 0.22$ & $* *$ \\
\hline \multirow{3}{*}{ Juiciness } & $<3$ & $6.66^{\mathrm{b}} \pm 0.21$ & $7.35^{\mathrm{a}} \pm 0.11$ & $6.82^{\mathrm{b}} \pm 0.30$ & $* * *$ \\
\hline & $4-6$ & $6.53^{b} \pm 0.25$ & $7.05^{\mathrm{a}} \pm 0.25$ & $6.78^{\mathrm{ab}} \pm 0.11$ & $* *$ \\
\hline & $7-9$ & $6.22 \pm 0.67$ & $6.71 \pm 0.17$ & $6.67 \pm 0.30$ & NS \\
\hline \multirow{3}{*}{ Tenderness } & $<3$ & $7.17^{\mathrm{b}} \pm 0.35$ & $7.99^{\mathrm{a}} \pm 0.21$ & $7.42^{\mathrm{ab}} \pm 0.26$ & $* * *$ \\
\hline & $4-6$ & $6.44^{\mathrm{b}} \pm 0.25$ & $7.35^{\mathrm{a}} \pm 0.65$ & $6.95^{\mathrm{ab}} \pm 0.33$ & * \\
\hline & $7-9$ & $6.03^{\mathrm{b}} \pm 0.05$ & $6.63^{\mathrm{a}} \pm 0.35$ & $6.63^{a} \pm 0.28$ & * \\
\hline \multirow{3}{*}{$\begin{array}{c}\text { Instrumental } \\
\text { tenderness }(\mathrm{N})\end{array}$} & $<3$ & $30.27^{\mathrm{a}} \pm 8.20$ & $15.83^{b} \pm 2.14$ & $15.12^{\mathrm{b}} \pm 0.24$ & $* * *$ \\
\hline & $4-6$ & $42.89^{a} \pm 2.68$ & $20.49^{\mathrm{b}} \pm 1.09$ & $16.97^{\mathrm{c}} \pm 1.04$ & $* * *$ \\
\hline & $7-9$ & $55.52^{\mathrm{a}} \pm 2.37$ & $24.73^{b} \pm 2.16$ & $24.80^{\mathrm{b}} \pm 6.80$ & $* * *$ \\
\hline
\end{tabular}

${ }^{\mathrm{abc}}$ Means bearing different superscripts are significantly different $(\mathrm{P}<0.05),{ }^{* * *} \mathrm{P}<0.0001,{ }^{* *} \mathrm{P}<0.01,{ }^{\star} \mathrm{P}<$ $0.05, \mathrm{NS}=$ Non Significant, $\mathrm{SD}=$ Standard Deviation. The 9-point scales used to assess meat quality attributes were: Flavour: $9=$ like extremely, $8=$ like very much, $7=$ like moderately, $6=$ like slightly, $5=$ neither like nor dislike, 4 = dislike slightly, 3 = dislike moderately, $2=$ dislike very much, $1=$ dislike extremely, Tenderness: $9=$ extremely tender, $8=$ very much tender, $7=$ moderately tender, $6=$ slightly tender, $5=$ neither tender nor tough, $4=$ slightly tough, $3=$ moderately tough, $2=$ very much tough, $1=$ extremely tough; and Juiciness: $9=$ extremely juicy, $8=$ very much juicy, $7=$ moderately juicy, $6=$ slightly juicy, 5 = neither juicy nor dry, 4 = slightly dry, 3 = moderately dry, 2 = very much dry, 1 = extremely dry.

categories determined in the present study was not necessary to reflect the effects of breeds and ages as Harar and Arsi breeds were reared in mixed crop livestock production system while Boran cattle was raised in a ranch system. Eating qualities are considered as the most important meat quality trait for consumer satisfaction, with juiciness, tenderness and flavour being the major attributes [3] [12] [13]. Attributes such as tenderness, color, flavor, juiciness and water holding capacity have an effect on consumer satisfaction [14] [15] [16]. The most necessary factor of meat high-quality in beef is sensory or eating quality, defined as tenderness, juiciness and flavour, which are generally assessed by way of a skilled taste panel [17] [18]. At 7 - 9 years mean flavor of Borana was significantly higher $(\mathrm{P}<0.05)$ than flavor from the Arsi breed. The higher flavor of Borana over Arsi bulls may be due to the accumulation of motr intramuscular fat in the former than the latter. Relatively lower mean flavor score (5.47) were reported for Arsi cattle [19] and grass fed beef cattle [20] [21].

At age $<3$ years mean sensory juiciness of Borana cattle was higher $(\mathrm{P}<0.05)$ than Arsi. The mean juiciness value of Arsi ( 7 - 9 years) was similar to mean $(6.23 \pm 0.21)$ reported for Dajal males cattle [34]. At age $<3$ years mean sensory 
tenderness of Borana was significance different $(\mathrm{P}<0.05)$ from Arsi. In agreement with the present study low sensory beef tenderness $(5.43 \pm 1.24)$ was reported in South Africa [35]. At the age of $4-6$ years mean sensory tenderness of Arsi was lower than $(\mathrm{P}<0.05)$ Borana. Normal ranges of sensory score for flavor were between 5.39 - 5.93, for juiciness between 4.38 - 5.60 and tenderness 5.50 6.47 [22]. The mean sensory tenderness of Arsi at $4-6$ and $7-9$ years, Borana and Harar at 7 - 9 years fall within this normal range based on the above suggestion. In all bulls across age categories as age advance sensory tenderness and juiciness were decreased while flavor increased. Similar decrease in juiciness, tenderness and increases flavor were reported as cattle advances in age [23].

\subsubsection{Effect of Age and Breeds of Cattle on Instrumental Tenderness}

In all age categories mean instrumental tenderness values of Arsi were higher ( $P$ $<0.05$ ) than Borana and Harar (Table 2). The mean WBSF of Arsi at $<3$ years was similar with values $(29.45 \mathrm{~N})$ reported for Longissimus thoracis muscle [24]. The higher WBSF of Arsi beef compared to Borana and Haraghe need further investigation whether management during rearing or genetics of animals was the cause for the difference. Moreover, Arsi breed is used for draft power for a longer period comparted to the Harar cattle breeds while Borana has no exposure to draft purpose as it comes from pastoral region.

In the present study the mean values of instrumental tenderness at $<3$ years was similar to the reported for four Canadian beef cattle which was $30.35 \mathrm{~N}$ [25]. The instrumental tenderness value of beef from Borana and Harar bulls was lower than shear force values of $37.71 \mathrm{~N}$ and $42.66 \mathrm{~N}$ reported for Brazilian cattle [26].

\subsubsection{Effect of Breeds of Cattle on Sensory and Instrumental Tenderness}

Breeds of cattle had affected $(\mathrm{P}<0.05)$ the instrumental tenderness of beef. Mean instrumental tenderness value for Arsi breed was higher $(\mathrm{P}<0.05)$ than Borana and Harar breeds (Table 3 ). Age by breed interaction showed highly significant $(\mathrm{P}<0.05)$ on instrumental tenderness and flavor. Instrumental tenderness, flavor, juiciness and tenderness were significantly affected $(P<0.05)$ by breeds and age. The influence of breeds on instrumental tenderness and sensory characteristics was probably due to the fact that different breeds of cattle have different muscle arrangements [27] [28] [29]. The higher mean instrumental tenderness value of the Arsi breed was an indication of its toughness. Mean flavor and juiciness value of the Arsi breed was lower $(\mathrm{P}<0.05)$ than the value for Borana and Harar breeds. The cause for the difference in tenderness, flavor and juiciness between Arsi and other breeds under study needs further investigation.

According to the ranges of classification [9] for very tender (WBS $<31.4 \mathrm{~N}$ ), tender $(31.4 \mathrm{~N}<\mathrm{WBS}<38.3 \mathrm{~N})$, Intermediate $(38.3 \mathrm{~N}<\mathrm{WBS}<45.1 \mathrm{~N})$ and tough (WBS > 45.1), the quality of beef in different age groups and breeds in the present study could be considered good except for beef from Arsi bulls between 4 and 9 years (Table 4). The better tenderness of beef from Borana and Harar bulls might be due to the higher content of marble fat of the breeds than Arsi. 
Table 3. Effect of breeds of cattle on sensory and instrumental tenderness.

\begin{tabular}{ccccc}
\hline \multirow{2}{*}{ Factors } & $\begin{array}{c}\text { Instrumental } \\
\text { tenderness }\end{array}$ & Flavor & Juiciness & Tenderness \\
\cline { 2 - 5 } & Mean $\pm \mathrm{SD}$ & Mean $\pm \mathrm{SD}$ & Mean $\pm \mathrm{SD}$ & Mean $\pm \mathrm{SD}$ \\
\hline Breed & $* * *$ & $* *$ & $* * *$ & $* * *$ \\
Arsi & $40.60^{\mathrm{a}} \pm 0.51$ & $6.97^{\mathrm{b}} \pm 0.51$ & $6.51^{\mathrm{c}} \pm 0.40$ & $6.65^{\mathrm{c}} \pm 0.57$ \\
Borana & $20.34^{\mathrm{b}} \pm 4.06$ & $7.37^{\mathrm{a}} \pm 0.63$ & $7.06^{\mathrm{a}} \pm 0.32$ & $7.37^{\mathrm{a}} \pm 0.70$ \\
Harar & $18.55^{\mathrm{b}} \pm 5.34$ & $7.26^{\mathrm{a}} \pm 0.44$ & $6.76^{\mathrm{b}} \pm 0.24$ & $7.02^{\mathrm{b}} \pm 0.43$ \\
Age & $* * *$ & $* * *$ & $* *$ & $* * *$ \\
A $\times \mathrm{B}$ & $* *$ & $* *$ & $\mathrm{NS}$ & $\mathrm{NS}$ \\
\hline
\end{tabular}

${ }^{\mathrm{abc}}$ Means bearing different superscripts are significantly different $(\mathrm{P}<0.05)$, ${ }^{* * *} \mathrm{P}<0.0001,{ }^{* *} \mathrm{P}<0.01,{ }^{*} \mathrm{P}<$ $0.05, \mathrm{SD}=$ Standard Deviation, $\mathrm{A} \times \mathrm{B}=$ Age $\times$ Breed.

Table 4. Effect of age and breeds instrumental beef warner-bratzler shear value classification $(\mathrm{N})$.

\begin{tabular}{ccccccc}
\hline & \multicolumn{9}{c}{ Breeds } \\
\cline { 2 - 7 } Age & \multicolumn{2}{c}{ Arsi } & \multicolumn{2}{c}{ Borana } & \multicolumn{2}{c}{ Harar } \\
\cline { 2 - 7 } & Mean & WBSF & Mean & WBSF & Mean & WBSF \\
\cline { 2 - 7 } & 30.27 & VT & 15.83 & VT & 15 & VT \\
$4-6$ & 42.89 & IM & 20.49 & VT & 17 & VT \\
$7-9$ & 55.52 & T & 24.73 & VT & 25 & VT \\
\hline
\end{tabular}

WBS $=$ Warner-Bratzler Shear, $\mathrm{N}=$ Newton, $\mathrm{VT}=$ Very Tender, $\mathrm{IM}=$ Intermediate, $\mathrm{T}=$ Tough.

\subsubsection{Effect of Age and Breeds of Cattle on meat Color and Water Holding Capacity}

Color is one of the most important quality parameters of beef, which is considered to be an indication of freshness and suitability for consumption [30]. The normal ranges for beef color and WHC were reported differently by different researchers. A research has reported ranges for $L^{*}=33.2-41, a^{*}=11-23.6, b^{*}$ $=6.1-11.3$ and $\mathrm{WHC}=37.0-72.7$ as normal $[22]$. Borana $(<3$ years $)$ beef was higher $(\mathrm{P}<0.05)$ in lightness $\left(\mathrm{L}^{*}\right)$ than Arsi and Harar cattle breed under the present study (Table 5). The result of the present finding almost agrees with the finding who reported $33.44 \pm 1.17$ for Polish Red-and-White and for Simmental (SM) bulls [31]. In all breeds beef redness $\left(a^{*}\right)$ and yellowness $\left(b^{*}\right)$ were similar across age categories. The result of the present finding agreed with other reports who did not found any variation in color values between bulls and steers of different breeds [32]. The mean of beef Lightness $\left(L^{*}\right)$ of Arsi, Borana and Harar cattle in all age categories fall within the normal ranges of meat quality [22] except for Borana and Arsi in the range 7 - 9 years, which was below the normal range. Even if statistically there were no significant difference $(P>0.05)$ among breeds and their age categories in yellowness $\left(\mathrm{b}^{\star}\right)$, Borans breed in all age cate- 
gories showed higher beef yellowness except for Arsi between 4 - 6 years. This might be due to the consumption of carotenoids that are found in plant as the breed was reared in ranch system while the other two in a mixed crop production system. However, beef color redness $\left(\mathrm{a}^{*}\right)$ and yellowness $\left(\mathrm{b}^{*}\right)$ of all cattle breeds across age categories is within the normal range.

Water Holding Capacity (WHC) is affected by post-mortem glycolysis, rate of carcass temperature and carcass fatness level [33] [34]. The mean water holding capacity of cattle breeds ranged from 69.13 - 73.10. This study showed that the mean water holding capacities of all slaughtered cattle were higher than the mean $(49.4 \pm 5.85)$ reported in some other studies for cattle slaughtered in Mekele, Ethiopia [35].

There was no variation $(\mathrm{P}>0.05)$ observed in water holding capacity between breeds across all age categories in the present study. The mean water holding capacity of breeds across age categories of the present study were found in the normal range of meat characteristics [22]. The color coordinates of beef from Arsi, Boran and Harar cattle breeds are shown in Figure 2. The mean lightness coordinate of the three breeds lied between 30 and 35 while the mean redness and yellowness lied between 10 and 15 .

Table 5. Effect of age and breeds of cattle on color characteristics and water holding capacity.

\begin{tabular}{|c|c|c|c|c|c|}
\hline \multirow{3}{*}{ Color } & \multirow{3}{*}{ Age } & \multicolumn{3}{|c|}{ Breed } & \multirow{3}{*}{$\mathrm{P}$ value } \\
\hline & & Arsi & Borans & Harar & \\
\hline & & Mean \pm SD & Mean \pm SD & Mean \pm SD & \\
\hline \multirow{3}{*}{ Lightness $\left(\mathrm{L}^{*}\right)$} & $<3$ & $32.10^{\mathrm{b}} \pm 1.78$ & $38.15^{\mathrm{a}} \pm 3.04$ & $32.19^{\mathrm{b}} \pm 1.22$ & $* *$ \\
\hline & $4-6$ & $33.32^{\mathrm{ab}} \pm 2.71$ & $32.73^{\mathrm{ab}} \pm 4.43$ & $33.15^{\mathrm{ab}} \pm 1.62$ & NS \\
\hline & $7-9$ & $28.81^{\mathrm{b}} \pm 0.84$ & $31.89^{\mathrm{b}} \pm 3.07$ & $33.63^{\mathrm{ab}} \pm 3.47$ & NS \\
\hline \multirow{3}{*}{ Redness $\left(a^{\star}\right)$} & $<3$ & $13.11 \pm 1.51$ & $11.57 \pm 0.90$ & $12.35 \pm 0.48$ & NS \\
\hline & $4-6$ & $12.96 \pm 0.90$ & $11.77 \pm 1.56$ & $12.70 \pm 0.52$ & NS \\
\hline & $7-9$ & $13.85 \pm 2.00$ & $14.02 \pm 1.58$ & $12.90 \pm 0.61$ & NS \\
\hline \multirow{3}{*}{ Yellowness $\left(b^{*}\right)$} & $<3$ & $11.14 \pm 1.23$ & $12.46 \pm 1.04$ & $10.96 \pm 1.52$ & NS \\
\hline & $4-6$ & $11.30 \pm 1.80$ & $10.80 \pm 1.76$ & $10.65 \pm 0.56$ & NS \\
\hline & $7-9$ & $10.58 \pm 1.06$ & $11.38 \pm 2.06$ & $11.30 \pm 1.75$ & NS \\
\hline \multirow{3}{*}{ WHC } & $<3$ & $73.10 \pm 1.85$ & $68.80 \pm 3.76$ & $70.97 \pm 3.24$ & NS \\
\hline & $4-6$ & $68.83 \pm 2.45$ & $69.13 \pm 3.96$ & $69.90 \pm 3.60$ & NS \\
\hline & $7-9$ & $71.56 \pm 1.50$ & $73.58 \pm 0.99$ & $71.92 \pm 2.23$ & NS \\
\hline
\end{tabular}

${ }^{\mathrm{abc}}$ Means bearing different superscripts are significantly different $(\mathrm{P}<0.05),{ }^{* * *} \mathrm{P}<0.0001,{ }^{* *} \mathrm{P}<0.01,{ }^{\star} \mathrm{P}<$ $0.05, \mathrm{NS}=$ Non Significant, WHC $=$ Water Holding Capacity, SD $=$ Standard Deviation. 


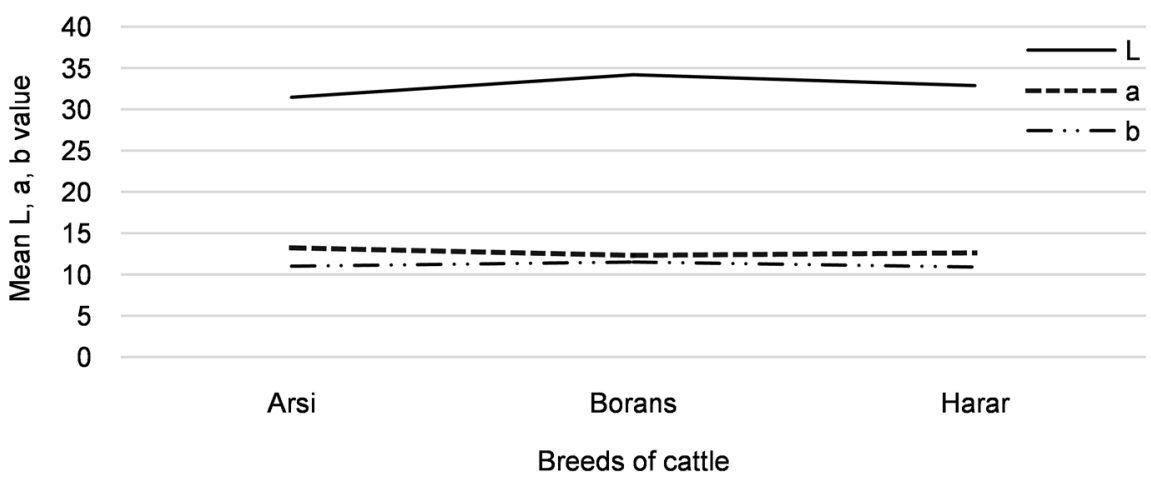

Figure 2. Mean color coordinate (L, a and b) of beef from Arsi, Boran and Harar cattle breeds.

\section{Conclusion and Recommendations}

From this study, it was concluded that beef from bulls of Harar and Boran breeds produced very tender beef while beef from the Arsi breed was intermediate in tenderness. Moreover, beef from Harar and Boran breed can be used up to the age of 9 years as they produce tender beef throughout while beef from the Arsi breed can be used to the age of 3 years as the meat become intermediate and tough as the age advance. The cause for tough beef production from the Arsi breed beyond the age of 3 years needs further investigation.

\section{Acknowledgements}

Many of the research findings highlighted in this article were funded in whole by the United States Agency for International Development (USAID) Bureau for Food Security under Agreement \# AID-OAA-L-15-00003 as part of Feed the Future Innovation Lab for Livestock Systems. Any opinions, findings, conclusions, or recommendations expressed here are those of the authors alone.

\section{Conflicts of Interest}

The authors declare no conflicts of interest regarding the publication of this paper.

\section{References}

[1] Abebe, B. (2014) Small Scale Beef Cattle Fattening Practices, on Farm Performance Evaluation and Opportunities for Market Orientation in Western Hararghe Zone, Chiro District. M.Sc. Thesis, Haramaya University, Haramaya.

[2] Bonny, S.P.F., Gardner, G.E., Pethick, D.W., Legrand, I., Polkinghorne, R.J. and Hocquette, J.F. (2014) Biochemical Measurements of Beef Are a Good Predictor of Untrained Consumer Sensory Scores across Muscles. Animal, 9, 179-190. https://doi.org/10.1017/S1751731114002389

[3] O'Quinn, T.G., Legako, J.F., Brooks, J.C. and Miller, M.F. (2018) Evaluation of the Contribution of Tenderness, Juiciness, and Flavor to the Overall Consumer Beef Eating Experience. Translational Animal Science, 2, 26-36. https://doi.org/10.1093/tas/txx008 
[4] Yesihak, M. and Webb, E.C. (2014) Ethiopian Beef Carcass Characteristics. African Journal of Agricultural Research, 9, 3766-3775. https://pdfs.semanticscholar.org/cede/1316bc7ca4852f95d5c2224ce3c2aae2f04e.pdf

[5] Tefera, T.D., Mummed, Y.Y., Kurtu, M.Y., Letta, M.U., O’Quine, T.G. and Vipham, J.L. (2019) Effect of Age and Breeds of Cattle on Carcass and Meat Characteristics of Arsi, Boran, and Harar Cattle in Ethiopia. Open Journal of Animal Sciences, 9, 367-383. https://doi.org/10.4236/ojas.2019.93030

[6] Yesihak, M. and Webb, E.C. (2015) Carcass Quality Audit-A Strategy to Improve Beef Sector in Ethiopia. African Journal of Agricultural Research, 10, 2731-2737. https://doi.org/10.5897/AJAR2015.9524

[7] Gadisa, B., Yesihak, Y. and Yousuf, M. (2019) Evaluation of Eating Quality in Sensory Panelist and Instrumental Tenderness of Beef from Harar, Arsi and Bale Cattle Breeds in Oromia, Ethiopia. International Journal of Agricultural Science and Food Technology, 5, 35-42. https://doi.org/10.17352/2455-815X.000039

[8] AMSA American Meat Science Association (2015) Research Guidelines for Cookery, Sensory Evaluation, and Instrumental Tenderness Measurements of Meat. 2nd Edition, Champaign. https://tinyurl.com/y5nrxrbc

[9] Shackelford, S.D., Morgan, J.B., Savell, J.W. and Cross, H.R. (1991) Identification of Threshold Levels for Warner-Bratzler Shear Force in Top Loin Steaks. Journal of Muscle Foods, 2, 289-296. https://doi.org/10.1111/j.1745-4573.1991.tb00461.x

[10] Kauffman, R.G., Eikelemboom, G., Vander, Wal, P.G. and Zaar, M.A. (1986) Comparison of Methods to Estimate Water-Holding Capacity in Postrigor Porcine Muscle. Meat Science, 18, 307-322. https://doi.org/10.1016/0309-1740(86)90020-3

[11] Trout, G.R. (1998) Techniques for Measuring Water Binding Capacity in Muscle Foods-A Review of Methodology. Meat Science, 23, 235-252. https://doi.org/10.1016/0309-1740(88)90009-5

[12] Troy, D.J. and Kerry, J.P. (2010) Consumer Perception and the Role of Science in the Meat Industry. A Review. Meat Science, 86, 214-226.

https://doi.org/10.1016/j.meatsci.2010.05.009

[13] Nian, Y., Kerry, J.P., Prendiville, R. and Allen, P. (2017) The Eating Quality of Beef from Young Dairy Bulls Derived from Two Breed Types at Three Ages from Two Different Production Systems. Irish Journal of Agricultural and Food Research, 56, 31-44. https://doi.org/10.1515/ijafr-2017-0003

[14] Dransfield, E., Martin, J.F., Bauchart, D., Abouelkaram, S., Lepetit, J., Culioli, J. and Picard, B. (2003) Meat Quality and Composition of Three Muscles from French Cull Cows and Young Bulls. Journal of Animal Science, 76, 387-399. https://doi.org/10.1017/S1357729800058616

[15] Hopkins, D.L. and Mortimer, S.I. (2014) Effect of Genotype, Gender and Age on Sheep Meat Quality and A Case Study Illustrating Integration of Knowledge. Meat Science, 98, 544-555. https://doi.org/10.1016/j.meatsci.2014.05.012

[16] Cafferky, J., Hamill, R.M., Allen, P., O’Doherty, J.V., Cromie, A. and Sweeney, T. (2019) Effect of Breed and Gender on Meat Quality of M. longissimus thoracis et Iumborum Muscle from Crossbred Beef Bulls and Steers. Foods, 8, 173.

https://doi.org/10.3390/foods8050173

[17] Dikeman, M., Pollak, E., Zhang, Z., Moser, D., Gill, C. and Dressler, E. (2005) Phenotypic Ranges and Relationships among Carcass and Meat Palatability Traits for Fourteen Cattle Breeds, and Heritabilities and Expected Progeny Differences for Warner-Bratzler Shear Force in Three Beef Cattle Breeds. Journal of Animal Science, 83, 2461-2467. https://doi.org/10.2527/2005.83102461x 
[18] Warren, H.E., Scollan, N.D., Nute, G.R., Hughes, S.I., Wood, J.D. and Richardson, R.I. (2008) Effects of Breed and a Concentrate or Grass Silage Diet on Beef Quality in Cattle of 3 Ages. II: Meat Stability and Flavor. Meat Science, 78, 270-278.

http://www.sciencedirect.com https://doi.org/10.1016/j.meatsci.2007.06.007

[19] Gebeyehu, A., Yousuf, M. and Sebsibe, A. (2013) Evaluation of Eating Qualities of Ethiopian Beef of Arsi Cattle in Adama Town, Oromia, Ethiopia. International Journal of Agriculture Innovations and Research, 1, 177-182.

[20] Brewer, P. and Calkins, C. R. (2003) Quality Traits of Grain- and Grass-Fed Beef: A Review. Nebraska Beef Cattle Reports, Article No. 221. https://digitalcommons.unl.edu/animalscinbcr/221

[21] Ullah, N., Shah, A.A., Nazar, M., Ali, G., Khan, I.U., Rahman, A., Kaka, N.A., Mugabe, W. and Shah, I.A. (2016) Influence of Breed, Age and Sex of Indigenous Cattle on Sensory Parameters of Raw and Cooked Beef Meat at Peshawar. Journal of Life Science and Biotechnology, 1, 477-506.

[22] Muchenje, V., Dzama, K., Chimonyo, M., Strydom, P.E., Hugo, A. and Raats, J.G. (2009) Some Biochemical Aspects Pertaining to Beef Eating Quality and Consumer Health: A Review. Food Chemistry, 112, 279-289.

https://doi.org/10.1016/j.foodchem.2008.05.103

[23] Shackelford, S.D., Koohmaraie, M. and Wheeler, T.L. (1995) Effects of Slaughter Age on Meat Tenderness and USDA Carcass Maturity Scores of Beef Females. Journal of Animal Science, 73, 3304-3309. http://jas.fass.org/content/73/11/3304 https://doi.org/10.2527/1995.73113304x

[24] Prajwal, S., Vasudevan, V.N., Sathu, T., Irshad, A. and Sunanda, C. (2017) Characterization of Buffalo Meat Using Principal Component Analysis. International Journal of Livestock Research, 7, 251-260. https://doi.org/10.5455/ijlr.20170524114102

[25] Puente, J., Samanta, S.S. and Bruce, H.L. (2016) Instrumental Meat Quality Characteristics Associated with Aged M. Longissimus thoracis from the Four Canadian Beef Quality Grades. Canadian Journal of Animal Science, 96, 143-153.

http://www.nrcresearchpress.com/cjas https://doi.org/10.1139/cjas-2015-0131

[26] Giusti, J., Castan, E., Pai, M.D., De Beni Arrigoni, M., Baldin, S.R. and De Oliveira, H.N. (2013) Expression of Genes Related to Quality of Longissimus dorsi Muscle Meat in Nellore (Bos indicus) and Canchim (5/8 Bos taurus $\times 3 / 8$ Bos indicus) Cattle. Meat Science, 94, 247-252. https://doi.org/10.1016/j.meatsci.2013.02.006

[27] Sañudo, C., Sierra, I., Albertí, P., Ertbjerg, P., Chistiansen, M., Gigli, S., Failla, S., Gaddini, A., Hocquette, J.F., Jailer, R., Nute, G.R. and Williams, J.L., et al. (2004) Carcass Quality of Several European Cattle Breeds Preliminary Results. Proceedings of 50 th International Congress of Meat Science and Technology, Helsinki, 8-13 August 2004, 516-518.

[28] Waritthitham, A., Lambertz, C., Langholz, H.J., Wicke, M. and Gauly, M. (2010) Assessment of Beef Production from Brahman $\times$ Thai Native and Charolais $\times$ Thai Native Crossbred Bulls Slaughtered at Different Weights. II: Meat Quality. Meat Science, 85, 196-200. https://doi.org/10.1016/j.meatsci.2009.12.025

[29] Xie, X., Meng, Q., Cui, Z. and Ren, L. (2012) Effect of Cattle Breed on Meat Quality, Muscle Fiber Characteristics, Lipid Oxidation and Fatty Acids in China. Asian-Australasian Journal of Animal Sciences, 25, 824-831.

https://doi.org/10.5713/ajas.2011.11462 
[30] Czyżak-Runowska, G., Grześ, B., Pospiech, E., Komisarek, J., Okulicz, M., Stanisławski, D. and Markiewicz-Kęszycka, M. (2017) Meat Quality of Limousin Young Bulls Slaughtered at 6, 9 and 12 Months of Age. Emirates Journal of Food and Agriculture, 29, 792-798. http://www.ejfa.me https://doi.org/10.9755/ejfa.2017.v29.i10.1297

[31] Sosin-Bzducha, E. (2017) Comparison of Meat Quality of the Polish Red-and-White and Simmental Young Bulls. Animal Science, 56, 129-136.

https://www.researchgate.net/publication/319656444

https://doi.org/10.22630/AAS.2017.56.1.15

[32] Moran, L., O’Sullivan, M.G., Kerry, J.P., Picard, B., McGee, M., O’Riordan, E.G. and Moloney, A.P. (2017) Effect of a Grazing Period Prior to Finishing on a High Concentrate Diet on Meat Quality from Bulls and Steers. Meat Science, 125, 76-83. https://doi.org/10.1016/j.meatsci.2016.11.021

[33] Oliveira, D.M., Ladeira, M.M., Chizzotti, M.L., Neto, O.M., Ramos, E.M., Gonçalves, T.M., Bassi, M.S., Lanna, D.P. and Ribeiro, J.S. (2011) Fatty Acid Profile and Qualitative Characteristics of Meat from Zebu Steers Fed with Different Oilseeds. Journal of Animal Science, 89, 2546-2555. https://doi.org/10.2527/jas.2010-3553

[34] Ustuner, H., Yalcintan, H., Orman, A., Ardicli, S., Ekiz, B., Gencoglu, H. and Kandazoglu, O. (2017) Effects of Initial Fattening Age on Carcass Characteristics and Meat Quality in Simmental Bulls Imported from Austria to Turkey. South African Journal of Animal Science, 47, 194-201. https://doi.org/10.4314/sajas.v47i2.11 https://www.ajol.info/index.php/sajas/article/view/155479

[35] Gebrehiwot, H.W., Balcha, E., Hagos, Y. and Wrkelul, K. (2008) Determination of ph and Water Holding Capacity of Beef from Selected Butcher Shops of Mekelle, Ethiopia. Academic Journals Expand Your Knowledge, 10, 159-164. https://academicjournals.org/journal/JVMAH/article-abstract/5837B7757243. 